\title{
Segregation of On and Off Bipolar Cell Axonal Arbors in the Absence of Retinal Ganglion Cells
}

\author{
Emine Günhan-Agar, Dianna Kahn, and Leo M. Chalupa \\ Section of Neurobiology, Physiology, and Behavior, Department of Psychology and Center for Neuroscience, University of \\ California, Davis, California 95616
}

Retinal cells that respond selectively to light onset or offset are segregated into On and Off pathways. Here, we describe the development of cone bipolar cells whose axonal arbors at maturity synapse onto ganglion cell dendrites confined to On and Off strata of the inner plexiform layer (IPL). In particular, we sought to determine whether the formation of this segregated pattern is dependent on the presence of ganglion cells. Developing bipolar cells were visualized using an antibody against recoverin, the calcium binding protein that labels On and Off cone bipolar cells in the adult rat retina. Recoverin-positive cells were apparent in the ventricular zone on the day of birth [postnatal day 0 (P0)], before bipolar cells begin to migrate to the inner nuclear layer. Two distinct strata were first apparent in the IPL at P8, with the Off pathway maturing earlier than the On pathway. There was no indication of exuberant bipolar cell projections. Throughout development, there were also a small number of recoverin-positive cells of unknown origin in the ganglion cell layer.
To assess whether the formation of On and Off cone bipolar cell projections is dependent on the presence of ganglion cells, these target neurons were eliminated by unilateral section of the optic nerve. This was done on the day of birth, resulting in a total loss of ganglion cells 5-6 d before bipolar cell axons innervate the IPL. In retinas with optic nerve sections, On and Off cone bipolar cells were present, albeit at a lower than normal density, and the axonal arbors of these interneurons were organized into two distinct strata. This indicates that ganglion cells are not essential for the formation of segregated On and Off bipolar cell inputs. These results lend support to the hypothesis that specific ingrowth patterns of bipolar cell terminal arbors could regulate the formation of stratified retinal ganglion cell dendrites.

Key words: On and Off pathways; bipolar cells; ganglion cells; retina; recoverin; development
A fundamental feature of the vertebrate retina is the separation of On and Off channels into functionally and structurally distinct pathways (Famiglietti and Kolb, 1976; Nelson et al., 1978; Schiller, 1992). This organization begins with two types of cone bipolar cells, responding differentially to increments and decrements of light. The axons of these interneurons terminate in different sublaminae of the inner plexiform layer (IPL) in which they connect with functionally equivalent retinal ganglion cells. Thus, On cone bipolar cells innervate the dendrites of On ganglion cells stratified in the inner part of the IPL (sublamina b), whereas Off cone bipolar cells contact the dendrites of Off ganglion cells in the outer part of the IPL (sublamina a).

In contrast to this separation of On and Off pathways in the adult retina, early in development the dendrites of retinal ganglion cells ramify throughout the IPL. The restriction of these processes into On and Off sublaminae occurs during the period when bipolar cells form synapses with ganglion cells (Maslim and Stone, 1986; Maslim et al., 1986, 1988; Dann et al., 1988; Ramoa et al., 1988), implying a causal link between these two developmental events. In support of this hypothesis, treating the devel-

\footnotetext{
Received Aug. 24, 1999; revised Oct. 6, 1999; accepted Oct. 14, 1999.

This work was supported by National Science Foundation Grant IBN12593 and National Institutes of Health Grant EYO3391. We thank Dr. Alexander M. Dizhoor for his generosity in supplying us with the anti-recoverin antibody and Dr. Lamberto Maffei for assistance in optic nerve sections.

Correspondence should be addressed to Leo M. Chalupa, Neurobiology, Physiology, and Behavior, University of California, Davis, CA 95616. E-mail: lmchalupa@ucdavis.edu.

Copyright (C) 1999 Society for Neuroscience 0270-6474/99/200306-09\$15.00/0
}

oping retina with $\mathrm{APB}$, a glutamate agonist that hyperpolarizes On bipolar cells and rod bipolar cells thereby preventing their release of glutamate (Slaughter and Miller, 1981), has been found to perturb the stratification of ganglion cell dendrites (Bodnarenko and Chalupa, 1993; Bodnarenko et al., 1995). Retinas treated with APB early in development have a much higher than normal incidence of multistratified ganglion cells, and such cells have been found to respond to both light onset and light offset (Bisti et al., 1998).

To explain how bipolar cell activity could regulate the stratification of ganglion cells, a model has been proposed that assumes On and Off bipolar cells selectively innervate either the proximal or the distal aspect of initially multistratified dendrites (Bodnarenko et al., 1995, their Fig. 8). As yet, however, little is known about the development of bipolar cells or their early innervation patterns. To obtain such information, in the present study, we relied on an antibody against a calcium-binding protein, recoverin, which binds to two types of cone bipolar cells terminating in either the On or Off sublamina of the IPL in the adult rat retina (Milam et al., 1993; Euler and Wässle, 1995). Our results indicate that bipolar cells express this protein even before migrating from the ventricular zone and that the axons of these cells attain a restricted projection pattern within the On and Off sublaminae of the IPL early in development.

Our main objective was to determine whether retinal ganglion cells, the main targets of bipolar cells, are required for the segregation of bipolar cell axons into On and Off sublaminae of the IPL. Ganglion cells were depleted by sectioning an optic 
nerve in newborn rats, before the time when bipolar cells begin to innervate the IPL. This revealed that bipolar cells can form segregated On and Off projections in the absence of retinal ganglion cells, although this manipulation causes a significant decrease in the incidence of such interneurons. Thus, whereas the stratification of retinal ganglion cell dendrites into On and Off sublaminae is regulated by bipolar cell activity (Bodnarenko and Chalupa, 1993; Bodnarenko et al., 1995; Bisti et al., 1998), the segregation of On and Off bipolar cell axons is not dependent on the presence of ganglion cells.

\section{MATERIALS AND METHODS}

All procedures were performed in strict compliance with the protocol approved by the Animal Care and Use Committee of the University of California at Davis.

Surgical procedures. Time pregnant Long-Evans rats were obtained from Simonsen Laboratories (Gilroy, CA). Unilateral optic nerve sections were performed on the day of birth, defined as postnatal day $0(\mathrm{P} 0)$. The pups were anesthetized by hypothermia, and the frontal portion of the brain was exposed by an incision in the skin and skull. The frontal cortex and the optic nerve were aspirated under visual guidance using a blunt needle attached to a vacuum pump. Animals were returned to their mother after recovery until they were killed at 3-4 weeks of age.

Tissue preparation. Normal postnatal pups (between P0 and P16) and 3- to 4-week-old experimental animals (that had one optic nerve sectioned at $\mathrm{P} 0$ ) were killed by an intraperitoneal injection of sodium pentobarbital. The animals were then perfused transcardially with $4 \%$ paraformaldehyde solution, followed by $0.9 \%$ saline solution. The eyecups were removed, hemisected, and post-fixed with $4 \%$ paraformaldehyde.

Primary antibodies. A polyclonal antibody against $23 \mathrm{kDa}$ calciumbinding protein, recoverin (gift from Dr. A. Dizhoor, Wayne State University, Detroit, MI), was used at dilutions of 1:10000-1:20000 to label the bipolar cells.

A monoclonal antibody against the Thy1.1 surface glycoprotein (clone OX-7; Chemicon, Temecula, CA) was used at dilutions of 1:10000-1: 20000 to label retinal ganglion cells.

A monoclonal antibody against the rat rhodopsin antigen (clone RETP1; Biodesign International, Kennebunk, ME) was used at dilutions of 1:50-1:100 to label rod photoreceptors.

Secondary antibodies. All of the secondary antibodies were purchased from Jackson ImmunoResearch (West Grove, PA). Cy-3-conjugated goat anti-rabbit $\operatorname{IgG}$ (1:200 dilution) or biotnylated goat anti-rabbit IgG (1:500 dilution) for recoverin and biotnylated goat anti-mouse $\operatorname{IgG}(1: 500$ dilution) for Thy1.1 was used as secondary antibodies. For double labeling with recoverin and rhodopsin antibodies, rhodamine redX-conjugated goat anti-rabbit $\operatorname{IgG}$ (1:200 dilution) and biotnylated goat anti-mouse IgG (1:500 dilution) were used. Both antibodies were prepared for doublelabeling experiments to prevent cross-reaction with opposite species. Streptavidin-conjugated Alexa-408 fluorescent probe (Molecular Probes, Eugene, OR) was used to visualize rhodopsin immunolabeling.

Immunohistochemistry. After post-fixation for 2-4 hr, hemisected eyes were immersed in gradually increasing concentrations of sucrose solution $(5,15$, and $30 \%)$ to cryoprotect the tissue. Vertical sections were taken at a thickness of $10-15 \mu \mathrm{m}$ on a cryostat and mounted on subbed slides. All incubations were performed at room temperature. Sections were preincubated in blocking solution [ $10 \%$ normal goat serum, $0.3 \%$ Triton $\mathrm{X}-100$, and $1 \%$ bovine serum albumin in PBS] for $1 \mathrm{hr}$. The primary antibodies were diluted in blocking solution. The sections were incubated in the primary antibody solution for 1-2 hr. After several washes with PBS, the sections were incubated in the secondary antibody diluted in blocking solution for 1-2 hr. Primary antibody incubation was omitted for control slides in each procedure.

To minimize the high background problem caused by Thy1.1 primary antibody in rat retina, we used the indirect tyramide signal amplification method (NEN Life Science, Boston, MA) for Thy1.1 immunostaining. After incubation with primary and biotnylated secondary antibodies, sections were incubated with streptavidin-HRP (diluted 1:100 in blocking buffer) for $30 \mathrm{~min}$, followed by incubation with the amplification agent for $10 \mathrm{~min}$. Streptavidin-HRP incubation was repeated, and peroxidase was visualized with $0.001 \%$ DAB and $0.003 \% \mathrm{H}_{2} \mathrm{O}_{2}$ in PBS.

The indirect immunofluroscence technique was used to visualize recoverin immunolabeling for quantitative analysis. After incubation with primary and biotnylated secondary antibodies, sections were incubated for $1 \mathrm{hr}$ in the Vectastain Elite ABC kit (Vector Laboratories, Burlingame, $\mathrm{CA}$ ), and peroxidase was visualized with $0.001 \% \mathrm{DAB}$ and $0.003 \%$ $\mathrm{H}_{2} \mathrm{O}_{2}$ in PBS.

For double-labeling studies, sections were incubated in a mixture of two primary antibodies, rinsed with PBS, and incubated in a mixture of two secondary antibodies.

After final washes, slides for epifluroscence and confocal microscopy were coverslipped with Citifluor (Ted Pella, Redding, CA), and slides for bright-field microscopy were coverslipped with Vectamount (Vector Laboratories).

Nissl staining. Vertical sections at a thickness of 20-25 $\mu \mathrm{m}$ were obtained on a cryostat for both experimental and control eyes. Sections were stained with $0.1 \%$ thionin in sodium acetate buffer for $2 \mathrm{hr}$ at room temperature. Slides were washed, dehydrated, and coverslipped with Vectamount.

1,1'-Dioctadecyl-3,3,3'3'-tetrametylindocarbocyanine perchlorate labeling. Six adult rats with unilateral optic nerve sections at P0 were perfused with $0.9 \%$ isotonic saline, followed by $4 \%$ paraformaldehyde. Both experimental and control eyes were removed and hemisected, and whole retinas were taken out. The retinas were embedded in 5\% agar, and vertical sections were obtained with a vibratome at a $200 \mu \mathrm{m}$ thickness. Crystals of 1,1'-dioctadecyl-3,3,3'3'-tetrametylindocarbocyanine perchlorate (DiI) (Molecular Probes, Eugene, OR) were put into the IPL or outer plexiform layer (OPL). Sections were kept in an oven $\left(37^{\circ} \mathrm{C}\right)$ for 12-24 hr to allow dye diffusion.

Imaging. Bright-field photomicrographs were taken by a digital camera (Optronics International, Chelmsford, MA) attached to a Nikon (Tokyo, Japan) eclipse E600 microscope and viewed by differential interference contrast optics. Confocal images for immunofluorescence and DiI labelings were acquired by either Bio-Rad (Hercules, CA) MRC 1024 ES or Leica (Nussloch, Germany) TCS-SP confocal microscope equipped with argon-krypton laser in epifluorescence-confocal mode. Three lines (488, 568, and 647) in argon-krypton laser, Nomarski filters, and prisms, plus transmitted light detector, were used to create Nomarski images. A stack of images along the $z$-axis $(0.5-2.0 \mu \mathrm{m}$ steps) was collected for each slide. For illustrative purposes, selected images of DiI-labeled cells were printed and traced on a light box with drawing pens.

Cell counts. Recoverin-positive bipolar cells were counted in immunostained sections from six animals that had an unilateral optic nerve section at P0. Ten separate regions in each section (including peripheral, paracentral, and central retina) were counted, and four to six sections from each eye (six control and six experimental) were analyzed. Stereological techniques were used to determine the number of recoverinlabeled cells in the inner nuclear layer (INL) (Sterio, 1984; Braendgaard and Gundersen, 1986). From these counts, the number of cells per volume of INL was estimated using the following equation:

$$
N_{\mathrm{V} \text { Recoverin } / \mathrm{INL}}=N_{\mathrm{Recoverin}} /\left(A_{\mathrm{INL}}{ }^{*} H_{\mathrm{INL}} * a / p\right)
$$

where $N_{\mathrm{V}}$ Recoverin/INL is the number of recoverin-positive cells per volume of INL, $N_{\text {Recoverin }}$ is the number of recoverin-positive cells counted in 10-15 $\mu \mathrm{m}$ sections, excluding those that intersected the top of the section and two sides of the counting frame, $A_{\text {INL }}$ is the area of INL in the counting frame, $H_{\mathrm{INL}}$ is the height of the optical dissector (usually $15 \mu \mathrm{m})$, and $a / p$ is the area per point for the objective used $(100 \times, 1.30$ oil; Olympus Optical, Tokyo, Japan).

INL, IPL, and cell body measurements. The thickness of the INL and IPL and the soma size of the recoverin-labeled bipolar cells were measured in both the control and experimental animals using NIH Image software. Bright-field images viewed by Nomarski optics were captured on the computer screen using the digital camera attached to the microscope. Twelve measurements per section were taken (four each from the peripheral, paracentral, and central retina), and four to six sections were analyzed from each of the five animals that sustained optic nerve sections.

Statistical analysis. The data were analyzed by ANOVA using the general linear model procedure (SAS Institute, Cary, NC), followed by Duncan's multiple range test with a significance level of $p<0.05$.

\section{RESULTS}

Figure 1 illustrates the recoverin labeling pattern in the adult rat. As can be seen in the low-power photomicrographs obtained from the central (Fig. $1 A$ ) and peripheral (Fig. $1 B$ ) regions of the retina, recoverin labels the somas of bipolar cells in the INL, as 

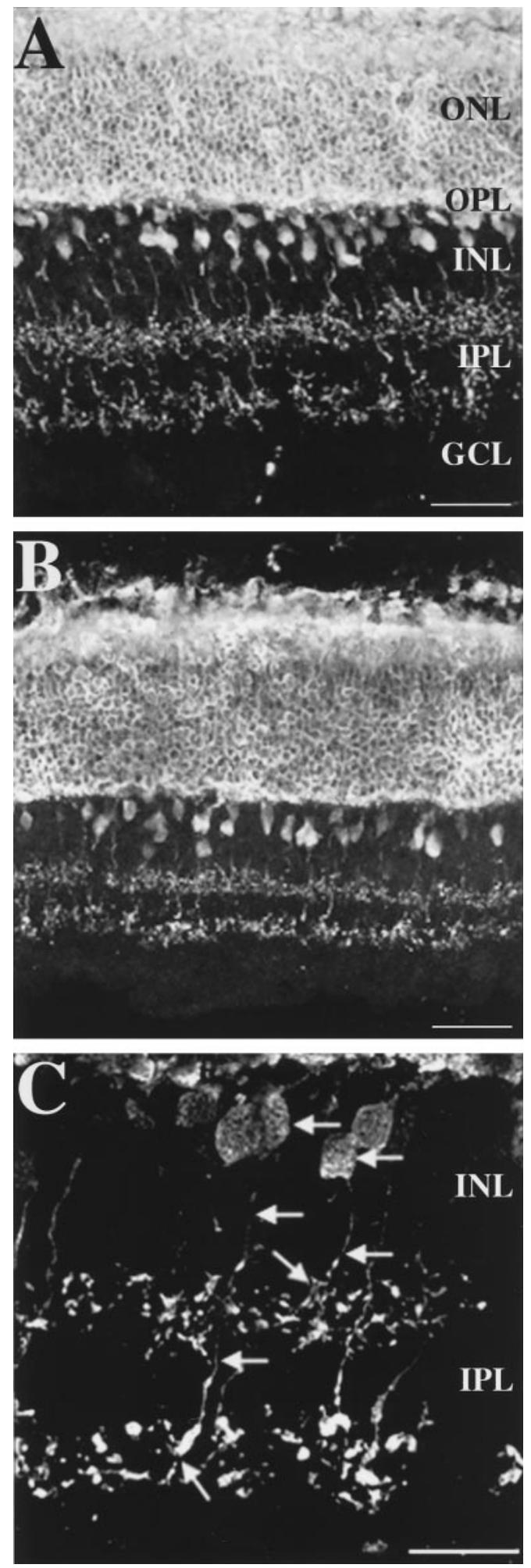

Figure 1. Confocal images of recoverin-labeled cells in the central $(A)$ and peripheral $(B)$ sections of the adult rat retina. In this and all other figures, the photoreceptor layer is $u p$, and the ganglion cell layer is down. Recoverin labels photoreceptors in the outer nuclear layer and two types of cone bipolar cells in the inner nuclear layer whose axon terminals form two strata in the inner plexiform layer. $C$, A higher power image illustrating two recoverin-labeled bipolar cells. Note that, in both cases, the axonal processes (indicated by arrows) could be visualized from the soma to the terminal in sublamina a (cell on the right) or in sublamina b (cell on the left). Scale bars, $50 \mu \mathrm{m}$. well as the processes of these interneurons that terminate in two distinct sublaminae of the IPL. Note that the separation between the On and Off strata in the IPL is greater in the central than the peripheral retina, reflecting central-to-peripheral differences in overall retinal thickness attributable to differential growth of the retina during development (Mastronarde et al., 1984; Lia et al., 1987; Kelling et al., 1989). Note also the intense staining of the photoreceptor layer, a feature that has been reported by others (Dizhoor et al., 1991; Milam et al., 1993). Shown at higher magnification in Figure $1 C$ are examples of recoverin-positive bipolar cells in which the axon and its terminal arbor can be visualized to originate from a single soma. In most cases, however, such continuity was not obvious because of the relatively thin sections used to ensure adequate penetration of the antibody.

Cells expressing recoverin were evident in the ventricular zone at P0 (data not shown). Figure 2 illustrates the developmental changes in recoverin labeling patterns between P1 and P12. As may be seen at P1, recoverin-positive cells are migrating from the ventricular zone toward the inner retina. At older ages (P3-P7), there is a progressive increase in the intensity of staining within the outer retina. At P6, recoverin-positive cells were noted within the INL (data not shown), and at P7, labeled terminal arbors were evident within the IPL (Fig. 2, arrow). In some cases, these could be observed to originate from presumed bipolar cells within the INL. By P8, a clear band of labeled processes was evident in the IPL (indicated by arrows), corresponding to sublamina a in which the axons of Off cone cells form synaptic contacts with the dendrites of Off ganglion cells. In comparison, there was only a hint of a laminar organization in the prospective sublamina $b$, corresponding to the On pathway (Fig. 2, inset). At P12, both the On and Off strata were clearly apparent, but note that at this age the On pathway is still less dense than in the adult animal (compare Fig. 2, P12, with Fig. 1A,B). By P16, recoverin labeling in both sublaminae appeared indistinguishable from that observed in the adult animal (data not shown).

Also clearly apparent in Figure 2 are recoverin-labeled cells within the developing ganglion cell layer. Such labeled profiles, first observed at P1, were present at all postnatal ages, as well as in the adult retina. In the adult retina (Fig. 3), these were variable in shape and size, and in many cases dendritic and/or axonal processes could be seen to originate from particular somas. The properties of such cells will be considered in detail elsewhere (Günhan-Agar and Chalupa, 1999, and forthcoming).

Because recoverin is expressed by photoreceptors that are born during an overlapping time period with bipolar cells (Morest, 1970; Rapaport and Vietri, 1991), we sought to determine whether cells could be double labeled by recoverin, as well as rhodopsin-specific antibodies. This revealed that, throughout development, a small proportion of recoverin-labeled cells were rods (data not shown). As expected, most of the rhodopsin labeling was confined to the ventricular zone and to the outer layers of the retina. However, a few rhodopsin-positive profiles were observed in the inner retina, including the INL and in the prospective ganglion cell layer. Presumably, these are rods that migrated inappropriately to the nuclear layers of the inner retina. Cells expressing rhodopsin were not found outside the photoreceptor layer in mature retinas (data not shown), which implies that such ectopic neurons were eliminated during the course of development by cell death.

In many developing systems, target neurons are known to play a crucial role in the establishment or the refinement of projection patterns, as well as in the survival of afferent neurons (Murphy 

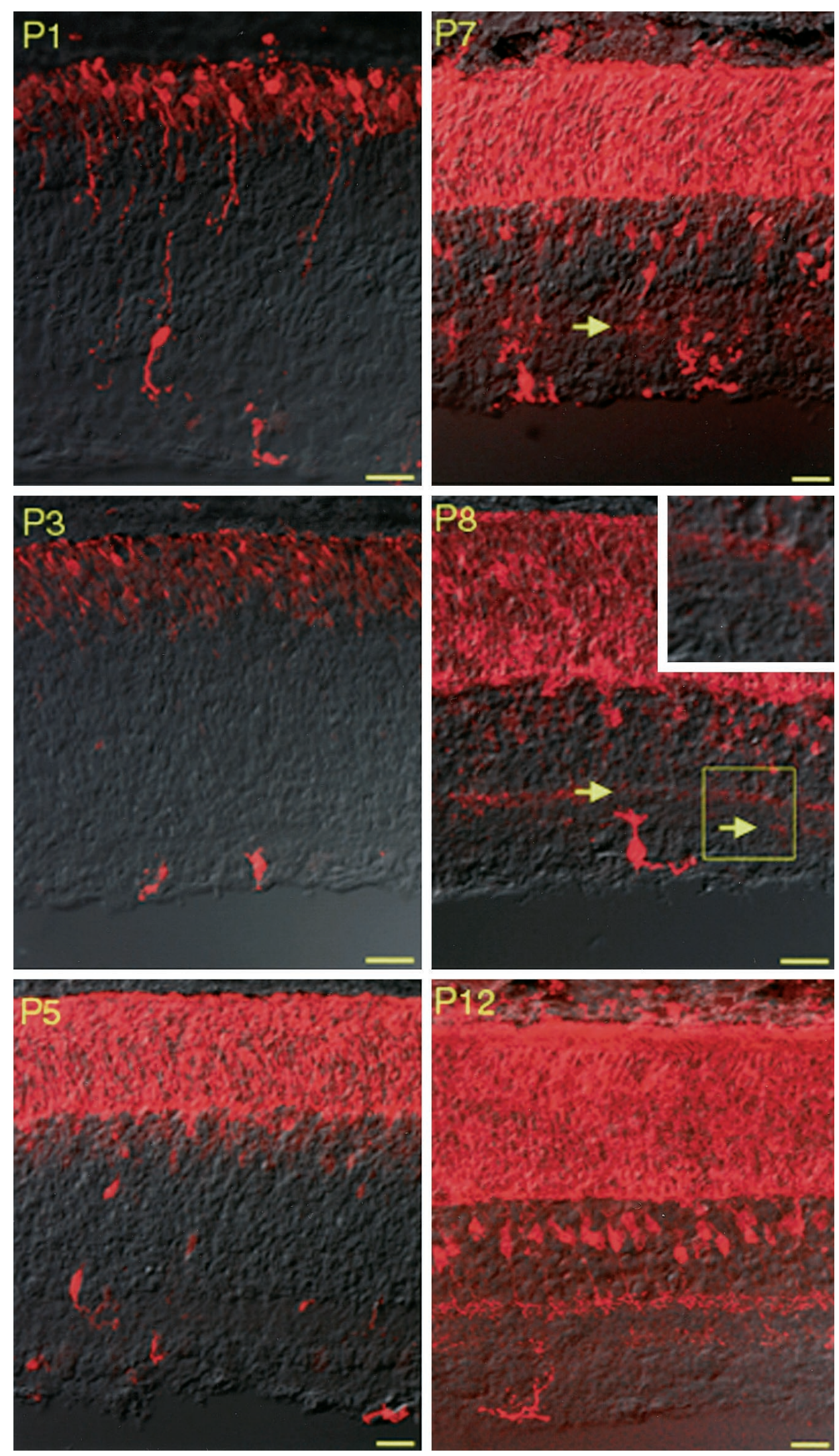

Figure 2. Superimposed confocal and Nomarski images of recoverin labeling patterns for P1-P12 rat retinas. Recoverin labels putative bipolar cells (as well as rod photoreceptors) in the ventricular zone and cells that are migrating toward the inner nuclear layer (P1-P5). At P7, some recoverin-labeled bipolar cells are present in the inner nuclear layer, and the axon terminals of these cells can be identified in the IPL (arrow). At P8, two strata of axon terminals in the IPL can be seen (arrows). At this age, the Off layer is well defined, whereas the On layer is just beginning to be formed. The inset shows a higher power image of the square indicated on the photomicrograph. By P12, both the On and Off strata are well defined. Note at all ages the presence of some recoverin-positive profiles in the ganglion cell layer. Scale bars, $20 \mu \mathrm{m}$. and Kalil, 1979; Oppenheim, 1981; Harvey and Robertson, 1992). To determine whether ganglion cells are essential for the segregated ingrowth patterns exhibited by developing On and Off bipolar cells, the target neurons were eliminated by sectioning the optic nerve. This was done at $\mathrm{P} 0$, a time before bipolar cell axons have innervated the IPL. Figure 4 compares retinal sections from an eye that had an optic nerve transected and a normal eye from the same animal stained for Nissl substance or processed for 

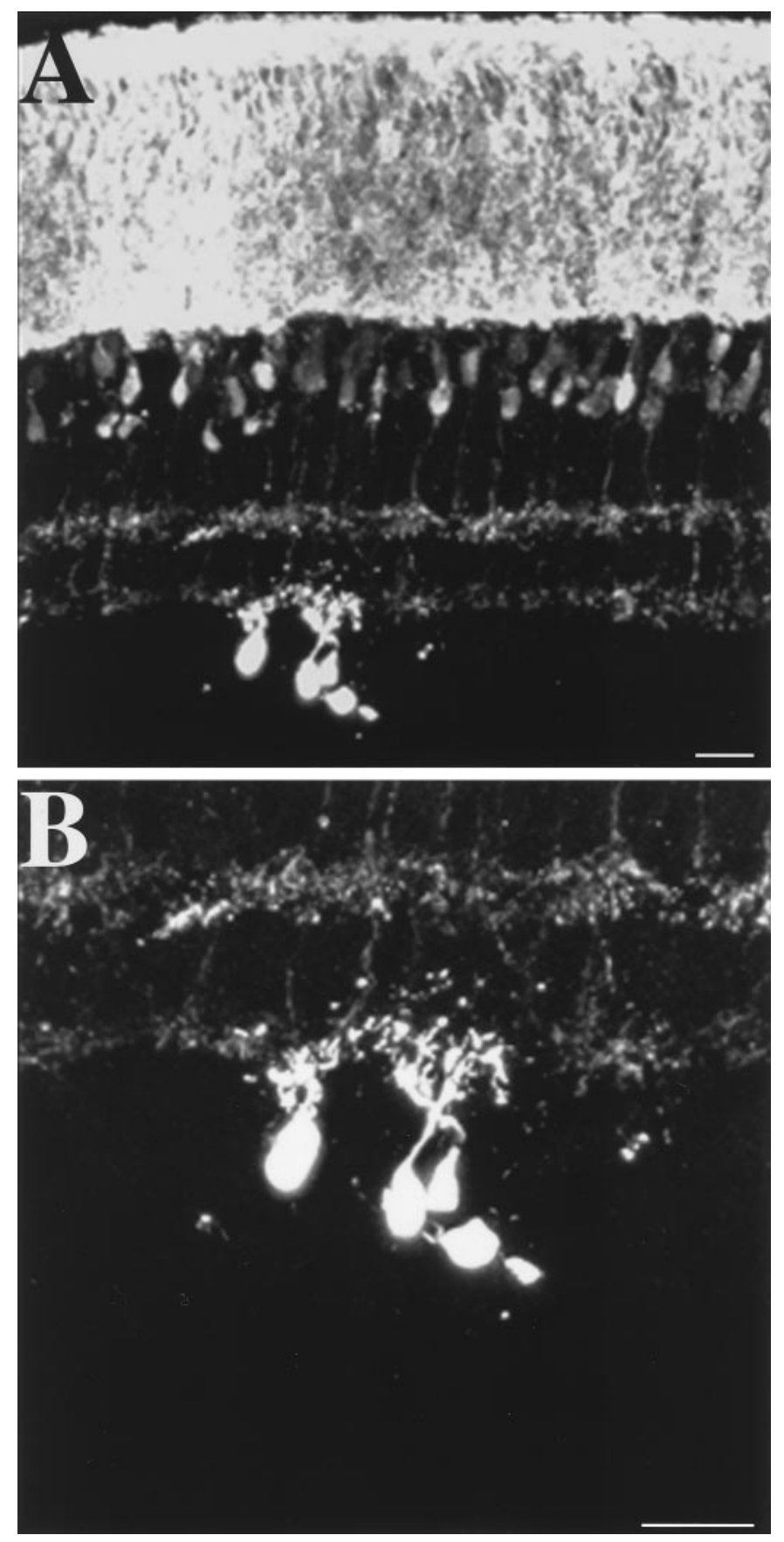

Figure 3. Confocal images of recoverin-labeled cells in the ganglion cell layer of the adult rat retina. $A$, Low-power image showing all retinal layers. $B$, Higher magnification of the recoverin-labeled cells in the ganglion cell layer. Scale bars, $20 \mu \mathrm{m}$.

Thy1.1, the ganglion cell-specific antibody (Beale and Osborne, 1982; Barnstable and Dräger, 1984; Barres et al., 1988). As may be seen in the eye with the transected optic nerve, there are no Thy1.1-labeled profiles, nor are there large Nissl-stained profiles in the ganglion cell layer. This was the case in every section examined from all six animals.

We next assessed whether or not retinal ganglion cells are required for the formation of segregated On and Off bipolar cell strata within the IPL. This was done by labeling cells with recoverin or with DiI after deposits of this tracer into the IPL or OPL in fixed sections.
Examination of the recoverin labeling in the INL of animals that sustained optic nerve sections revealed that bipolar cell axon terminals were stratified into two distinct layers within the IPL (Fig. 5). This was the case in all six animals in which this manipulation was performed. The retinas of the experimental animals were also substantially thinner than normal. To a large degree, this reflected the shrunken ganglion cell layer (Fig. 4), but measures of the other retinal layers revealed that the IPL was also significantly thinner so that the overall separation between the On and Off strata was less than normal. Counts of recoverin-positive profiles showed that the incidence of such neurons was also significantly lower in the retinas with optic nerve section, but soma size did not differ from normal. These measurements are summarized in Table 1.

The DiI labeling confirmed the segregation of bipolar cell terminals and provided additional information about the morphological properties of these neurons. As may be seen in Figure 6, the axons of individual neurons in both the normal and experimental animals terminated in a confined region of the IPL. An examination of 100 bipolar cells labeled with DiI in the experimental retinas and 130 such neurons in control retinas revealed no cells with bifurcating axonal processes. Moreover, the terminal arbors of all neurons, although showing considerable heterogeneity in size and shape, appeared confined to a given strata of the IPL. It should be noted that our deposits of DiI most likely labeled all classes of bipolar cells, not just those expressing recoverin (cf. Euler and Wassle, 1995).

\section{DISCUSSION}

We have shown that the antibody against the calcium binding protein, recoverin, which labels On and Off cone bipolar cells in the mature retina (Milam et al., 1993; Euler and Wässle, 1995), recognizes neurons presumed to be bipolar cells very early in development of the rat retina. Recoverin is also expressed by other retinal cell types, so we cannot establish the identity of every labeled cell. Indeed, a small proportion of the neurons expressing recoverin were rods, and some recoverin-positive cells (of unknown type) were observed in the ganglion cell layer. Still, the sequential changes in the recoverin labeling pattern, observed before the formation of two separate strata within the IPL, undoubtedly reflect the differentiation of cone bipolar cells and the ingrowth pattern of their axons.

The formation of stratified On and Off cone bipolar cell projections does not appear to involve an intermingling of the processes of these interneurons. Indeed, we are struck by the remarkable degree of specificity exhibited by On and Off bipolar cell axons. At P8, a clearly defined strata corresponding to terminals of Off cone bipolar cells is present, but at this age, the On strata is just beginning to appear. The earlier formation of the Off sublamina of the IPL observed here with recoverin immunocytochemistry corresponds to the temporal sequence of synapse formation between bipolar cells and ganglion cells noted in the developing monkey retina (Okada et al., 1994). Because our material does not provide the degree of resolution necessary to assess subtle changes in projection patterns, we cannot rule out some refinements in the axonal processes of developing bipolar cells. Such restructuring must be relatively subtle, however, compared with that of ganglion cell dendrites when they change from a multistratified to a unistratified state (Maslim et al., 1986; Dann et al., 1988; Maslim and Stone, 1988; Ramoa et al., 1988; Kirby and Steineke, 1991). The ingrowth pattern exhibited by bipolar cell axons also contrasts with the exuberance and subsequent 

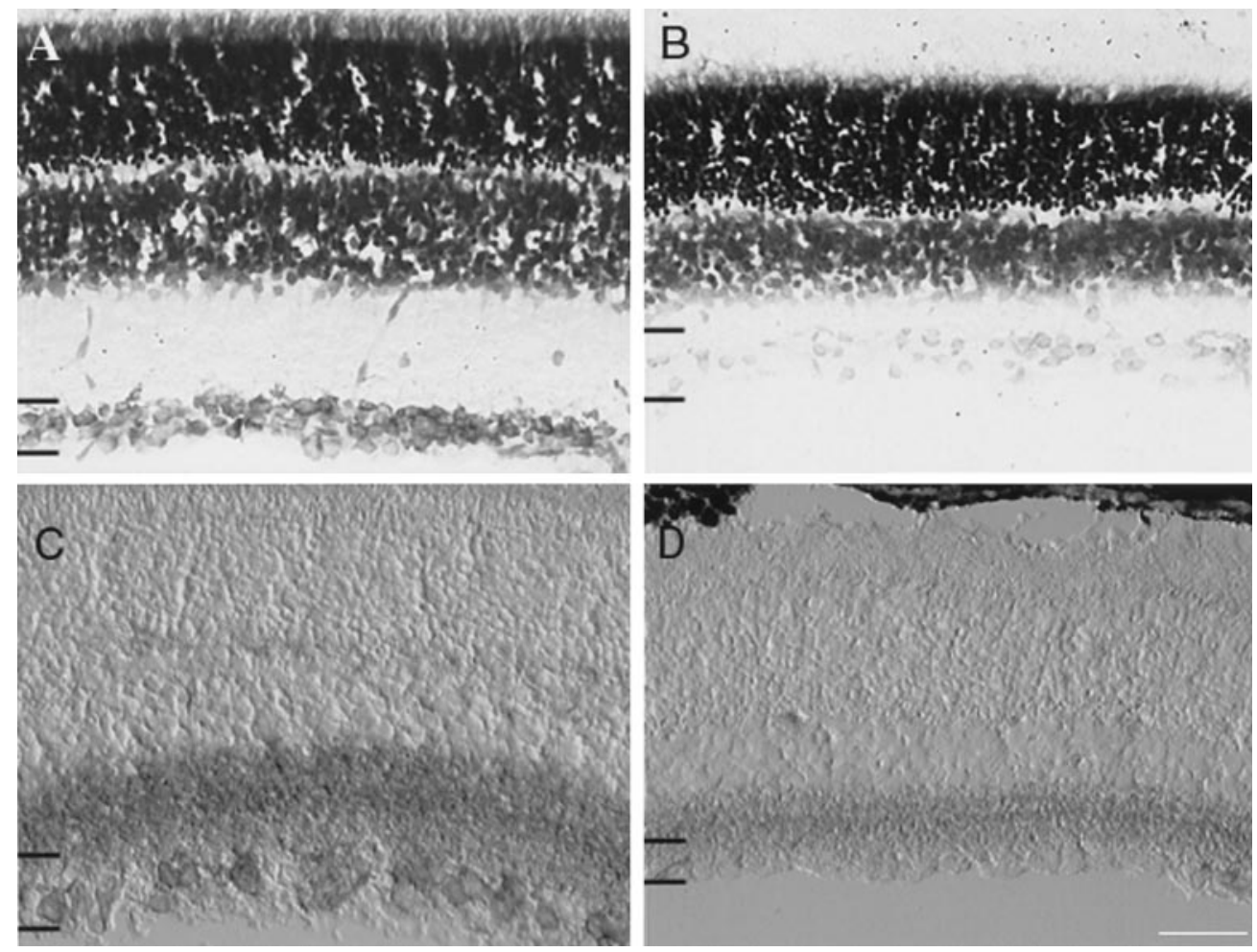

Figure 4. Bright-field-Nomarski images of Nissl $(A, B)$ and Thy1.1 $(C, D)$ stainings in normal $(A, C)$ and optic nervetransected rat retinas $(B, D)$. Black lines indicate the limits of the ganglion cell layer in all four pictures. Note that the large Nissl-stained cells and Thy1.1labeled cells are missing in the ganglion cell layer of optic nerve-transected retinas $(B, D)$. Scale bar, $50 \mu \mathrm{m}$.

retraction evident in On and Off retinogeniculate projections of the ferret (Hahm et al., 1991). Interestingly, bipolar cells in developing ferrets have been reported recently to exhibit a degree of developmental specificity analogous to what we have observed in the rat retina (Miller et al., 2000).

\section{Stratification of bipolar cells after ganglion cell loss}

Previous studies have shown that optic nerve section in the neonatal rat results in rapid and complete loss of ganglion cells, with most cells dying within 48 hr of this procedure (Perry et al., 1983; Osborne and Perry, 1985; Beazley et al., 1987; Rabacchi et al., 1994). Thus, we estimate that, in the present study, most ganglion cells were eliminated by optic nerve section 5-6 d before the ingrowth of bipolar cell axons into the IPL, at approximately P7. Counts of recoverin-labeled cells in the INL showed that this manipulation also produced significant alterations in the organization of the INL and the IPL, including a significant decrease in the number of recoverin-labeled cells within the INL. Although it has been reported that section of the optic nerve does not cause a significant loss of neurons within the INL, this conclusion was based on counts of the total number of cells in Nissl-stained sections (Beazley et al., 1987). More recently, a significant loss in vasoactive intestinal peptide and choline acetyltransferase immunoreactive amacrine cells has been noted after optic nerve section in the adult rat (Wright and Ball, 1999). Our results could reflect the selective cell loss of recoverin-labeled bipolar cells or the loss of recoverin immunoreactivity in these neurons. At present, we have no way of distinguishing between these alternatives, but intuitively it seems more likely that depletion of the ganglion cell population by optic nerve section would cause some loss of afferents to these neurons.

This raises the question of why certain recoverin-immunoreactive bipolar cells would be eliminated while others (the majority) would survive after section of the optic nerve. One possibility is that the bipolar cells that were lost failed to make synaptic contacts with ganglion cells or with interneurons eliminated by the optic nerve section. The lack of such targets would presumably deprive these afferents of essential trophic factors, leading to their elimination. Along the same line, the bipolar cells that survived optic nerve section may be neurons that make synaptic contacts primarily with amacrine cells that were unaffected by ganglion cell loss. This explanation assumes that cone bipolar cells in the rat comprise different subtypes based on their synaptic contacts, as has been demonstrated in the cat retina (Cohen and Sterling, 1990).

Despite these changes in the inner nuclear and synaptic layers, a large contingent of recoverin-positive cells remained in the INL of the eye that sustained section of the optic nerve. Perhaps the most remarkable observation was that the terminal processes of these cone bipolar cells were clearly segregated into two distinct strata, corresponding to the On and Off sublaminae present in the normal retina. It should be emphasized that retinal ganglion cells were depleted by optic nerve section $\sim 5-6 \mathrm{~d}$ before bipolar cells innervate the IPL. This indicates that the segregation of On and Off cone bipolar cells into two segregated On and Off pathways is not dependent on retinal ganglion cells, the major target of these interneurons.

What might regulate the segregated On and Off cone bipolar cell axons? One possibility is that the formation of two distinct strata in the IPL by the terminal arbors of these neurons reflects an intrinsic program. Although this cannot be ruled out, we think it unlikely given the extensive literature on the role of cell-cell interactions in the formation of specific innervation patterns (Tessier-Lavigne and Goodman, 1996). More likely, some external factor provides a signal to the cone bipolar cells to form terminals in one or the other sublamina of the IPL. If this was the case, one would expect that there should be some type of stratified "signal" within the developing IPL at or before the time that bipolar cells begin to innervate this layer. One possibility is the 

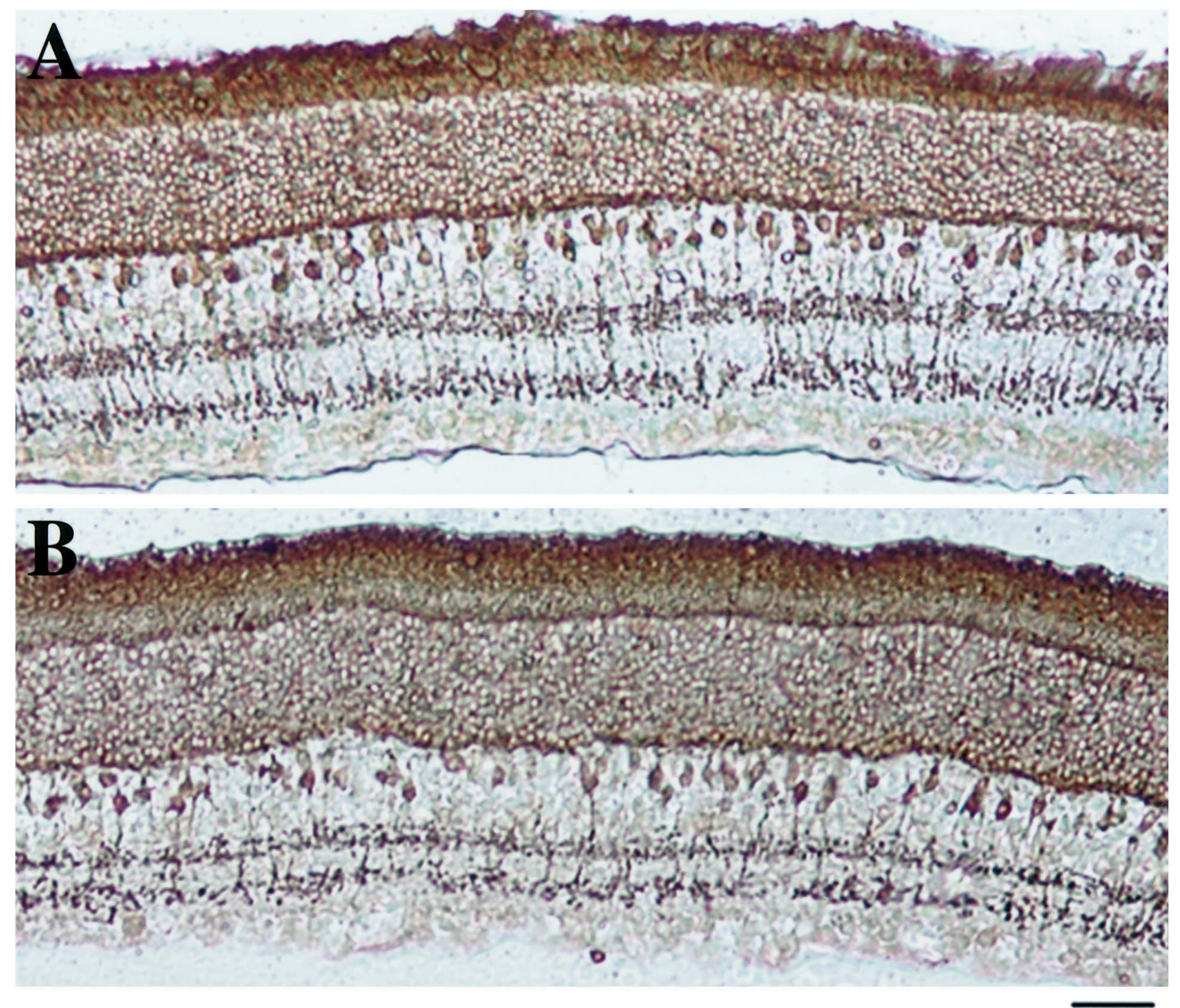

Figure 5. Bright-field images of recoverin labeling in the normal $(A)$ and optic nerve-transected $(B)$ retinas. Note that the labeling patterns are the same in both cases, although the density of labeled cells in the inner nuclear layer and the distance separating the two strata in the inner plexiform layer are less in $B$ than in $A$. Scale bar, $50 \mu \mathrm{m}$.

differential distribution of molecules in the extracellular matrix, as has been found in the developing cortex (cf. Pearlman and Sheppard, 1996). Alternatively, there could be stratified cellular targets, present before the ingrowth of bipolar cell axons. A possible candidate for this role are the processes of cholinergic cells (stemming from starburst amacrine cells), which at maturity are stratified into sublaminae a or b (Famiglietti et al., 1977; Famiglietti, 1983a,b, 1985; Masland et al., 1984; Tauchi and Masland, 1984; Bloomfield and Miller, 1986). In both the chick (Layer et al., 1997) and in the rat (Koulen, 1997), immunocytochemical

Table 1. Quantitative analysis of recoverin-immunostained retinas

\begin{tabular}{lcc} 
& Control & Optic nerve transection \\
\hline Recoverin-positive cells in INL $\left(\text { cells } / \mathrm{mm}^{3}\right)^{*}$ & $189161 \pm 33390(n=6)$ & $125919 \pm 14636(n=6)$ \\
Soma size of recoverin-positive cells $(\mu \mathrm{m})$ & $8.88 \pm 0.99(n=5)$ & $8.93 \pm 0.71(n=5)$ \\
Width of INL $(\mu \mathrm{m})$ & $47.29 \pm 3.88(n=5)$ & $44.83 \pm 3.51(n=5)$ \\
Width of IPL $(\mu \mathrm{m})^{*}$ & $35.74 \pm 8.41(n=5)$ & $29.64 \pm 4.53(n=5)$ \\
On and Off sublaminae separation $(\mu \mathrm{m})^{*}$ & $23.63 \pm 3.97(n=5)$ & $16.44 \pm 2.17(n=5)$
\end{tabular}

Values are mean $\pm \mathrm{SD} .{ }^{*} p<0.01$, Duncan's multiple range test. 


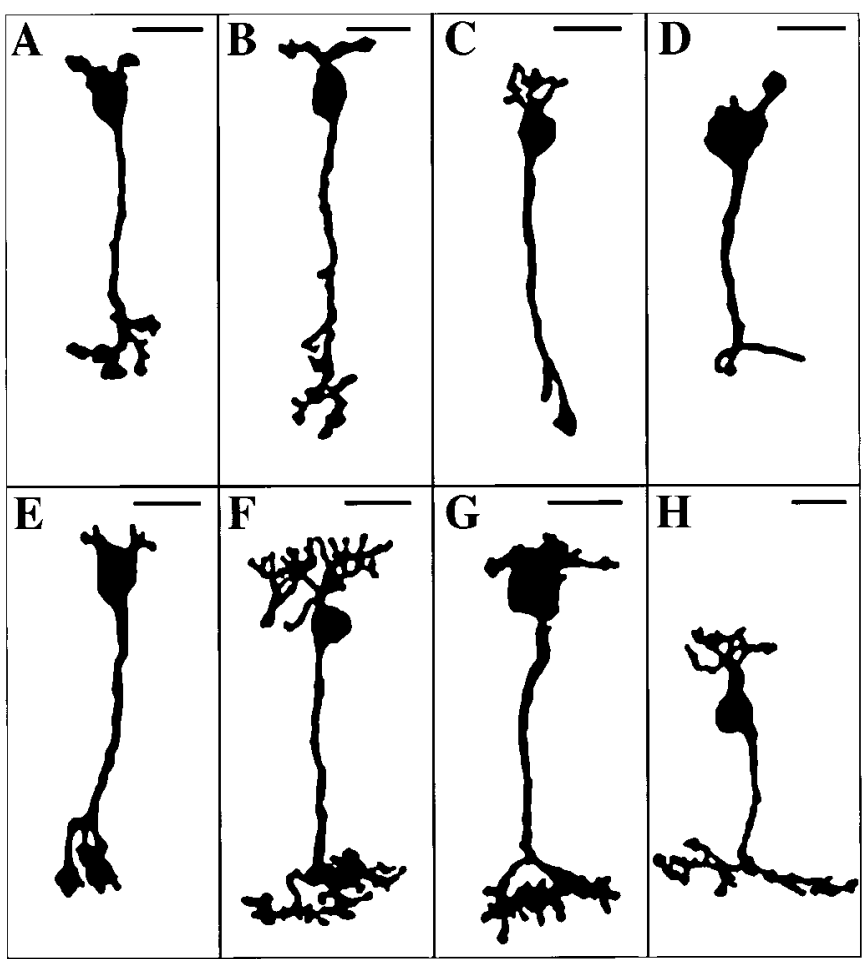

Figure 6. Drawings of DiI-labeled bipolar cells. $A-D$ are bipolar cells from normal retinas, and $E-H$ are bipolar cells from optic nervetransected retinas. Note that, in all cases, the axons terminate in a confined region of the inner plexiform layer. Scale bar, $10 \mu \mathrm{m}$.

studies have shown that cholinergic-positive strata are detectable very early in the developing retina. Indeed, in the rat, two bands of cholinergic processes have been detected as early as P3, some $5 \mathrm{~d}$ before we observed the presence of stratified terminal arbors within the IPL as defined by their expression of recoverin. This temporal sequence of events implies that the cholinergic strata within the developing IPL could act as a scaffold for the later segregated ingrowth of cone bipolar cell axons. One way to test this idea would be to assess the effects of perturbing the cholinergic cells on the formation of segregated bipolar cell innervation patterns, analogous to what was done here with respect to the ganglion cell population. Such studies using specific cholinergic neurotoxins are now in progress.

\section{Functional implications}

The pattern of bipolar cell ingrowth observed here is in line with the model proposed for explaining how bipolar cell afferent activity could regulate the stratification of retinal ganglion cell dendrites (Bodnarenko et al., 1995, their Fig. 8). Besides the selective innervation of ganglion cell dendrites by ingrowing On or Off bipolar cells, the model stipulates the functional activation of bipolar cell-ganglion cell synaptic contacts at a time when the dendrites of ganglion cells are still in an immature multistratified state. According to this model, On or Off bipolar cells innervate either the distal or the proximal aspect of initially multistratified dendrites, and for a given ganglion cell, glutamate-mediated activity would subsequently "validate" synaptic contacts within either the On or Off sublaminae of the IPL. Thus, immature multistratified ganglion cells should respond to light with only On or Off discharge patterns. It should be possible to test this assumption by combining patch-clamp recordings from developing ganglion cells with intracellular labeling of these neurons.

\section{REFERENCES}

Barnstable CJ, Dräger UC (1984) Thy-1 antigen: a ganglion cell specific marker in rodent retina. Neuroscience 11:847-855.

Barres BA, Silverstein BE, Corey DP, Chun LL (1988) Immunological, morphological, and electrophysiological variation among retinal ganglion cells purified by panning. Neuron 1:791-803.

Beale R, Osborne NN (1982) Localization of the Thy-1 antigen to the surfaces of rat retinal ganglion cells. Neurochem Int 4:587-595.

Beazley LD, Perry VH, Baker B, Darby JE (1987) An investigation into the role of ganglion cells in the regulation of division and death of other retinal cells. Brain Res 430:169-184.

Bisti S, Gargini C, Chalupa LM (1998) Blockade of glutamate-mediated activity in the developing retina perturbs the functional segregation of ON and OFF pathways. J Neurosci 18:5019-5025.

Bloomfield SA, Miller RF (1986) A functional organization of ON and OFF pathways in the rabbit retina. J Neurosci 6:1-13.

Bodnarenko SR, Chalupa LM (1993) Stratification of ON and OFF ganglion cell dendrites depends on glutamate-mediated afferent activity in the developing retina. Nature 364:144-146.

Bodnarenko SR, Jeyarasasingam G, Chalupa LM (1995) Development and regulation of dendritic stratification in retinal ganglion cells by glutamate-mediated afferent activity. J Neurosci 15:7037-7045.

Braendgaard H, Gundersen HJ (1986) The impact of recent stereological advances on quantitative studies of the nervous system. J Neurosci Methods 18:39-78.

Cohen E, Sterling P (1990) Demonstration of cell types among cone bipolar neurons of cat retina. Philos Trans R Soc Lond B Biol Sci 330:305-321.

Dann JF, Buhl EH, Peichl L (1988) Postnatal dendritic maturation of alpha and beta ganglion cells in cat retina. J Neurosci 8:1485-1499.

Dizhoor AM, Ray S, Kumar S, Niemi G, Spencer M, Brolley D, Walsh KA, Philipov PP, Hurley JB, Stryer L (1991) Recoverin: a calcium sensitive activator of retinal rod guanylate cyclase. Science 251:915-918.

Euler T, Wässle H (1995) Immunocytochemical identification of cone bipolar cells in the rat retina. J Comp Neurol 361:461-478.

Famiglietti Jr EV (1983a) On and off pathways through amacrine cells in mammalian retina: the synaptic connections of "starburst" amacrine cells. Vision Res 23:1265-1279.

Famiglietti Jr EV (1983b) "Starburst" amacrine cells and cholinergic neurons: mirror-symmetric on and off amacrine cells of rabbit retina. Brain Res 261:138-144.

Famiglietti EV (1985) Starburst amacrine cells: morphological constancy and systematic variation in the anisotropic field of rabbit retinal neurons. J Neurosci 5:562-577.

Famiglietti Jr EV, Kolb H (1976) Structural basis for ON-and OFFcenter responses in retinal ganglion cells. Science 194:193-195.

Famiglietti Jr EV, Kaneko A, Tachibana M (1977) Neuronal architecture of on and off pathways to ganglion cells in carp retina. Science 198:1267-1269.

Günhan-Agar E, Chalupa LM (1999) Recoverin labeled cells in the ganglion cell layer of the developing and mature rat retina. Soc Neurosci Abstr 25:1770.

Hahm JO, Langdon RB, Sur M (1991) Disruption of retinogeniculate afferent segregation by antagonists to NMDA receptors. Nature 351:568-570

Harvey AR, Robertson D (1992) Time-course and extent of retinal ganglion cell death following ablation of the superior colliculus in neonatal rats. J Comp Neurol 325:83-94.

Kelling ST, Sengelaub DR, Wikler KC, Finlay BL (1989) Differential elasticity of the immature retina: a contribution to the development of the area centralis? Vis Neurosci 2:117-120.

Kirby MA, Steineke TC (1991) Early dendritic outgrowth of primate retinal ganglion cells. Vis Neurosci 7:513-530.

Koulen P (1997) Vesicular acetylcholine transporter (VAChT): a cellular marker in rat retinal development. NeuroReport 8:2845-2848.

Layer PG, Berger J, Kinkl N (1997) Cholinesterases precede "ON-OFF" channel dichotomy in the embryonic chick retina before onset of synaptogenesis. Cell Tissue Res 288:407-416.

Lia B, Williams RW, Chalupa LM (1987) Formation of retinal ganglion cell topography during prenatal development. Science 236:848-851.

Masland RH, Mills JW, Hayden SA (1984) Acetylcholine-synthesizing amacrine cells: identification and selective staining by using radioautography and fluorescent markers. Proc R Soc Lond B Biol Sci 223:79-100. 
Maslim J, Stone J (1986) Synaptogenesis in the retina of the cat. Brain Res 373:35-48.

Maslim J, Stone J (1988) Time course of stratification of the dendritic fields of ganglion cells in the retina of the cat. Brain Res Dev Brain Res 44:87-93.

Maslim J, Webster M, Stone J (1986) Stages in the structural differentiation of retinal ganglion cells. J Comp Neurol 254:382-402.

Mastronarde DN, Thibeault, Dubin MW (1984) Nonuniform postnatal growth of the cat retina. J Comp Neurol 228:598-608.

Milam AH, Dacey DM, Dizhoor AM (1993) Recoverin immunoreactivity in mammalian cone bipolar cells. Vis Neurosci 10:1-12.

Miller ED, Tran M-N, Wong G-K, Oakley DM, Wong ROL (2000) Morphological differentiation of bipolar cells in the ferret retina. Vis Neurosci, in press.

Morest DK (1970) The pattern of neurogenesis in the retina of the rat. Z Anat Entwicklungsgesch 131:45-67.

Murphy EH, Kalil R (1979) Functional organization of lateral geniculate cells following removal of visual cortex in the newborn kitten. Science 206:713-716.

Nelson R, Famiglietti Jr EV, Kolb H (1978) Intracellular staining reveals different levels of stratification for on- and off-center ganglion cells in cat retina. J Neurophysiol 41:472-483.

Okada M, Erickson A, Hendrickson A (1994) Light and electron microscopic analysis of synaptic development in Macaca monkey retina as detected by immunocytochemical labeling for the synaptic vesicle protein, SV2. J Comp Neurol 339:535-558.

Oppenheim RW (1981) Cell death and related regressive phenomena; a selective historical review and progress report. In: Studies in developmental neurobiology: essays in honor of Viktor Hamburger, pp 24-133. New York: Oxford UP.
Osborne NN, Perry VH (1985) Effect of neonatal optic nerve transection on some classes of amacrine cells in the rat retina. Brain Res 343:230-235.

Pearlman AL, Sheppard AM (1996) Extracellular matrix in early cortical development. Prog Brain Res 108:117-135.

Perry VH, Henderson Z, Linden R (1983) Postnatal changes in retinal ganglion cell and optic axon populations in the pigmented rat. J Comp Neurol 219:356-368.

Rabacchi SA, Bonfanti L, Liu XH, Maffei L (1994) Apoptotic cell death induced by optic nerve lesion in the neonatal rat. J Neurosci 14:5292-5301.

Ramoa AS, Campbell G, Shatz CJ (1988) Dendritic growth and remodeling of cat retinal ganglion cells during fetal and postnatal development. J Neurosci 8:4239-4261.

Rapaport DH, Vietri AJ (1991) Identity of cells produced by two stages of cytogenesis in the postnatal cat retina. J Comp Neurol 312:341-352.

Schiller PH (1992) The ON and OFF channels of the visual system. Trends Neurosci 15:86-92.

Slaughter MM, Miller RF (1981) 2-Amino-4-phosphonobutyric acid: a new pharmacological tool for retina research. Science 211:182-185.

Sterio DC (1984) The unbiased estimation of number and sizes of arbitrary particles using the dissector. J Microsc 134:127-136.

Tauchi M, Masland RH (1984) The shape and arrangement of the cholinergic neurons in the rabbit retina. Proc $\mathrm{R}$ Soc Lond B Biol Sci 223:101-119.

Tessier-Lavigne M, Goodman CS (1996) The molecular biology of axon guidance. Science 274:1123-1133.

Wright AM, Ball AK (1999) Long-term changes in rat retinal amacrine cell density following optic nerve transection. Invest Ophthalmol Vis Sci [Abstr] 40:439. 